\title{
Calvyn se vierde diens, die doktore-amp, en artikel 18 van die kerkorde van Dordrecht 1618 en 1619: 'n Kritiese refleksie
}

Author:

Andries L. du Plooy

Affiliation:

${ }^{1}$ Faculty of Theology, North-West University,

Potchefstroom Campus,

South Africa

Correspondence to:

Andries du Plooy

Email:

dries.duplooy@nwu.ac.za

Postal address:

PO Box 20031, Noordbrug

2522, South Africa

Dates:

Received: 05 Sept. 2013

Accepted: 28 Feb. 2014

Published: 06 Nov. 2014

How to cite this article: Du Plooy, A.L., 2014, 'Calvyn se vierde diens, die doktoreamp, en artikel 18 van die kerkorde van Dordrecht 1618 en 1619: 'n Kritiese refleksie', In die Skriflig 48(2), Art. \#1760, 11 pages. http://dx.doi.org/10.4102/ ids.v48i2.1760

\section{Copyright:}

(C) 2014. The Authors.

Licensee: AOSIS

OpenJournals. This work

is licensed under the

Creative Commons

Attribution License.
Die artikel fokus op Calvyn se besondere rol in die formulering van artikels 2 en 18 van die kerkorde van Dordrecht 1618 en 1619. Hierdie kerkorde word steeds deur 'n groot aantal gereformeerde kerke in die wêreld aanvaar en gebruik.

Onderwerpe en probleme wat aangeraak word, sluit vrae in soos die volgende: Wie is verantwoordelik vir die onderrig van Teologie? Is die tradisie geldig dat daar naas die drie dienste van Woordbedienaar, ouderling en diaken ook 'n vierde diens bestaan, naamlik dié van doktor in die Teologie? Kan hierdie tradisie, wat hoofsaaklik op die standpunte van Bucer en Calvyn berus, met die gegewens in die Bybel versoen word?

Besondere aandag word aan die volgende aspekte gegee:

- Historiese gegewens oor doktor in die Teologie met besondere verwysing na die standpunte en invloed van Calvyn.

- 'n Kritiese evaluering van die begronding van die vierde diens op die Bybel.

- Die verhouding tussen teologiese opleiding in die konteks van die kerk en/of 'n universiteit.

- Besondere aandag word gegee aan die situasie in die Gereformeerde Kerke in Suid-Afrika ten opsigte van die funksionering van hierdie vierde diens.

Van die belangrikste konklusies wat gemaak word, is die volgende: die kerk het deur die eeue 'n besondere waardering en respek gehad vir die taak en funksie van die doktore in die Teologie. Dit het inderdaad tot groot seën van die kerke gedien. Calvyn se standpunte het dikwels tot verwarring aanleiding gegee, maar andersyds ook bygedra tot die erkenning van die belangrike funksie of taak wat hierdie vierde diens kerklik verrig. Net so vervul die doktore in die Teologie 'n besondere wetenskaplike rol aan teologiese fakulteite van universiteite.

Calvin's fourth office, the doctor ministry, and article 18 of the church order of Dordrecht 1618 and 1619: A critical reflection. This article focuses on Calvin's special role in the ecclesiastical formulation of articles 2 and 18 in the church order of Dordrecht 1618 and 1619, which is still retained in a large number of reformed church orders in the reformed fellowship of churches.

Topics and issues which are addressed include questions such as: Who is responsible for the teaching of Theology? Is the tradition valid that the doctorial or professorial office in theology exists as a fourth office beside that of ministers, elders and deacons? Is this tradition, which mainly rests on the views of Bucer and Calvin, correct in terms of the Bible?

Particular attention to the following aspects is given:

- Historical data on the doctor ecclesiae focusing on the views and influence of Calvin.

- A critical evaluation of the foundation of the fourth office on the Bible.

- The relationship between theological training in the context of a church and/or a university.

- A special investigation of the situation within the Reformed Churches in South Africa in this regard.

Important conclusions are made, for example that the church through the ages had a very high esteem and respect for the office of the doctor in Theology; that this fourth office is still retained in many reformed churches, with great blessing. Calvin's views did cause some confusion on the one hand, but on the other hand it contributed to the acknowledgement of the important function the doctors in Theology have on behalf of the church and in the faculties of Theology at universities. 


\section{Inleiding}

In hierdie artikel word die fokus laat val op die besondere aandeel wat Calvyn gehad het in die kerklike formulering van artikels 2 en 18 van die kerkorde van Dordrecht (1618 en 1619), soos dit nog steeds in 'n groot aantal gereformeerde kerkordes binne die gereformeerde kerklike verband gehandhaaf word (vgl. GKSA 1998).

Hierdie artikel stel 'n aktuele saak in verband met die dosering van Teologie aan die orde. Die taak en rol van die Teologie in die kerk asook aan fakulteite van Teologie aan universiteite was en is steeds ' $n$ interessante onderwerp - iets waaroor verskillende standpunte gehandhaaf word. Veral sedert die twaalfde eeu met die ontstaan van universiteite tot vandag toe, is en bly die studie van die Teologie binne kerklike sfere sowel as aan universiteite 'n onderwerp van ernstige diskussie (Le Roux 2013:1-5).

Hierdie artikel handel oor vrae en aspekte soos wie verantwoordelik is vir die dosering van Teologie. Vrae soos die volgende is ook relevant: Is die tradisie en/of standpunt houdbaar, naamlik dat die diens of amp van doktor of professor in die Teologie 'n vierde afsonderlike diens naas dié van die bedienaars van die Woord, ouderlinge en diakens is? Is hierdie tradisie, wat veral op Calvyn en Bucer se standpunte berus, skriftuurlik korrek? Wat is die verhouding tussen die kerklike teologiese opleiding en universitêre teologiese opleiding? Is dit nodig dat Teologie opleiding hoegenaamd aan teologiese skole en/of universiteite moet plaasvind? Wat is die verskil tussen die missionale taak en roeping van die kerk ooreenkomstig veral artikel 7 van die kerkorde en die fokus op Teologie in terme van artikel 18 van die kerkorde, indien enige? Is Teologie 'n wetenskap of slegs 'n kerklike taak of roeping met die oog op die praktiese toerusting van studente vir die bediening van die evangelie?

Omdat dit onmoontlik is om aan al hierdie vrae reg te laat geskied, word slegs op die volgende aspekte gefokus:

- Die belangrikste historiese gegewens en riglyne oor die taak en funksie van die doctor Theologiae of professor in die Teologie, met die fokus op Calvyn se standpunte.

- Die tyd van die Reformasie van die sestiende en sewentiende eeue met besondere aandag aan die kerklike besluite en ontwikkelings.

- 'n Kritiese evaluering van die begronding van die vierde diens in die Skrif.

- Die verhouding tussen 'n kerklike en/of 'n universitêre teologiese opleiding.

- Die professor in Teologie soos dit veral binne die konteks, standpunte en omstandighede van die GKSA na vore kom.

- Enkele konklusies en perspektiewe.

\section{Calvyn se standpunte}

Daar is belangrike historiese gegewens en riglyne oor die taak en funksie van die doctor Theologiae of professor in die Teologie. In die gereformeerde teologiese en kerklike wêreld was daar altyd 'n mate van onduidelikheid oor die amp van doktor in die Teologie. Henderson (1962) het uitvoerig oor die doktore-amp (teaching office) in die reformatoriese tradisie geskryf en opnuut weer die aktualiteit daarvan beklemtoon. Hy is geprys vir die oorspronklike navorsing wat hy oor die onderwerp gedoen het. Dankbaar (1964-1965:135) het gebruik gemaak van Henderson se insigte om in 'n deeglike oorsig oor die standpunt van Calvyn aan te dui hoe belangrik die saak van leer en doseer in die kerk sedert die NuweTestamentiese tyd was. Die bewys hiervoor word gevind in die woord didaskalos wat herhaaldelik in die Nuwe Testament voorkom, asook in die diens van die doctores wat in die Ou Kerk en in die Middeleeue as 'n besonder belangrike amp geag is. Die doctor ecclesiae was destyds as 'n eretitel beskou. Die vraag is egter of die doktore-amp in die eintlike sin van die woord 'n kerklike amp is. Dankbaar (1964-1965:135) meen dat die onsekerheid wat tot vandag toe hieroor bestaan, grootliks aan Calvyn self toegeskryf kan word, veral omdat hy in sy uitsprake daaroor nie konsekwent was nie. Waarskynlik is die rede daarvoor dat Calvyn veral drie aspekte uitgelig het, naamlik dat die doktor in Teologie ' $n$ kerklike amp is, dat dit funksioneel van die herderlike funksie verskil en dat dit veral binne 'n akademiese arena funksioneer (Henderson 1962:41).

Die konteks en agtergrond waarteen Calvyn gewerk en geskryf het, speel myns insiens 'n belangrike rol in sy standpunte oor die sogenaamde vierde diens, of die doktore-amp. Hier word besonderlik gewys op die plek en funksie wat die teologiese doktor in die Middeleeuse kerk en samelewing gehad het, asook die invloed van Luther en veral die invloed van Bucer op Calvyn. Henderson (1962:21) meen egter dat hierdie wettige en vrugbare diens in die Middeleeue deur die Roomse Kerk 'had been corrupted which caused him to include it as an integral office of the public ministry of the church in its Reformed estate'.

\section{Middeleeuse konteks}

Die naam doctor was in die Vroeë Kerk geen aanduiding van 'n amp of 'n titel nie, maar het na iemand verwys wat ' $n$ bepaalde werk of funksie van lering vervul het. Doctor was die Latynse woord vir die Griekse didaskalos (Bouwman 1928:494).

Met die ontstaan van die universiteite in die twaalfde eeu het dit egter begin verander, omdat geleerde mense al hoe meer belangstelling getoon het in die ondersoek na die waarheid en die werklikheid; of meer presies gestel: omdat die kennis of wetenskap van die Kunste, die Regte, die Medisyne en veral die Teologie toegeneem en ontwikkel het. Aangesien die samelewing, vanweë die Roomse kerklike hiërargiese beskouings ook hiërargies georden was, is die studie van Teologie as die hoogste studieveld geag, veral omdat God as die hoogste beginsel van alles beskou is. Die doctores in die Teologie is gevolglik met baie gesag en eerbied bejeën. Hulle is as besonderlik begenadig 
beskou en as die vertolkers van die waarheid geag. In die kerk en die onderwys is van die doctores Theologiae verwag om die volgende te doen: 'legere' [doseer en onderrig], 'disputare' [die waarheid te verdedig en te formuleer], 'determinare' [te beslis of te bepaal], 'praedicare' [formeel te preek of te verkondig], en 'regere' [te regeer of te bestuur]. Dit het saamgetrek in die skool en die kerklike funksies (Posthumus Meyjes 1973:23-25).

Die reg en bevoegdheid om as ' $\mathrm{n}$ doctor (ook in die Teologie) te mag optree, is deur die universiteit verkry op grond van die verwerwing van die licentia docendi. Diegene wat hierdie promosie ontvang het, het deel van 'n besondere hoë stand (die sg. magisterium) geword. Hulle het dan die reg en plig gehad om met gesag in die bepaalde wetenskap werksaam te wees en daarin leiding te gee. Die lisensiaat is deur die kanselier van die universiteit, as verteenwoordiger van die pous self, aan die persoon toegeken. Hiermee was die ontvanger tot gehoorsaamheid en onderdanigheid aan die pous verplig (Bouwman 1928:495; Posthumus Meyjes 1973:27-31).

In die Teologie was die doctores veral verplig om met behulp van die wetenskap en met disputasies die geloof teenoor die ketters te verdedig en om die waarheid te ondersoek en te beskerm. Indien iemand dit sou nalaat, was hy ontrou aan sy magisterium en is dit as ' $n$ bewys van roepingsversaking beskou.

Die doctores was verplig om in hulle arbeid binne die dogma van die kerk te bly, maar is wel toegelaat om vry op te tree op gebiede en terreine van die wetenskap waaroor daar geen dogma of pouslike uitspraak bestaan het nie. In die geledere van die magisterium, onder die doctores, het 'n protes gegroei namate die kerklike kanonieke reg al intensiewer ontwikkel het en die wetenskap geknel het. Dit het in die laat-Middeleeue (14e - 15e eeue) tot spanning tussen die universiteite en die kerk gelei. Die opkoms van die Humanisme het ook daartoe bygedra dat die teologiese fakulteite aan universiteite hulle al hoe meer van die greep van die kerklike hiërargie losgemaak het (Posthumus Meyjes 1973:30-31).

Bouwman (1928:495) wys daarop dat die naam doctor mettertyd op die akademiese graad of akademiese kwalifikasie gedui het, terwyl die naam professor na iemand verwys het met ' $n$ vaste betrekking waaraan ' $n$ salaris van 'n universiteit gekoppel was. Calvyn het hierdie twee name later met mekaar vereenselwig.

\section{Luther se beskouing}

Ter illustrasie van die belangrikheid en relevansie van die status of erkenning wat aan die teologiese doktor as 'n kerklik-akademiese amp verleen is, kan verwys word na die verhaal van 'n weddenskap deur twee Duitse vriende wat op 20 Oktober 1538 in Londen gesluit is. Dit is deur Steinlein (1912:757) vermeld, wat 'n studie van Luther se doktorsgraad gemaak het. Dit is ook weer deur Posthumus Meyjes (1973:21 e.v.) aangehaal, asook deur Le Roux (1992:292).
Die weddenskap tussen Franz Burckhardt en Georg von Boyneburg het gegaan oor die vraag of Luther met sy optrede teen Tetzel in 1517 reeds 'n doktorsgraad gehad het of nie. Dit het dus oor sy geleerdheid en bevoegdheid gegaan, asook oor die kwessie of aan die reformatoriese optrede van Luther enige legitimiteit geheg sou kon word. Luther sou slegs geldigheid en legitimiteit vir sy optrede in 1517 kon opeis indien hy, binne die Roomse konteks van die Middeleeuse standpunte, wel oor die gesag en dus oor die graad in Teologie beskik het. Sonder ' $n$ graad sou hy bloot 'n indoctus gewees het, dus 'n ongeleerde en ongekwalifiseerde persoon.

Die twee Duitsers het aan die Dekaan van die Universiteit van Wittenberg geskryf, wat sedert 1535 Luther self was. Hy het toe aan die twee vriende die amptelike dokumente verskaf waarin dit duidelik is dat die officium doctoris reeds in 1512 op die gebruiklike wyse aan hom toegeken is. Dus, reeds vanaf die begin van die Reformasie - net soos in die tye daar voor - was dit vir die kerk belangrik dat die leraars of professore goed gekwalifiseerd moes wees. Luther kon hom daarop beroep dat hy nie as 'n gewone leek gepraat het nie, maar bevoeg en toegerus was om met gesag te praat. Hy het binne sy reg en bevoegdheid teen Tetzel opgetree (Posthumus Meyjes 1973:37).

Luther het ook in sy optrede op 31 Oktober 1517 met die 95 stellings wat hy opgestel en bekendgestel het, hom daarop beroep dat hy kragtens sy amp as doctor die plig het om oor die waarheid te waak. Tydens die Ryksdag van Worms in 1520 is die ban oor hom uitgespreek en is hierdie amp hom ontneem. Tog het hy hierdie amp van doctor Theologiae later weer vir homself toegeëien, eerstens om hom teenoor die geesdrywers en spiritualiste te stel en ook as 'n geleerde en toegeruste teoloog te onderskei. Verder het hy hom daarop beroep dat hy deur Christus self tot hierdie amp of taak geroep is. Hy dien dus in die diens van doktor in die Teologie op gesag van Christus wat hom daartoe geroep het en nie op gesag van die pous of 'n magisterium nie. Hiermee het Luther 'n nuwe oriëntering aan die teologiese doktor gegee: Christus is sy enigste Magister of Meester (Posthumus Meyjes 1973:37-38).

\section{Die standpunte van Bucer}

Martin Bucer word met reg beskou as die vader van die vier ampte of dienste in die kerk. Calvyn het met sy verblyf by hom in Straatsburg (1538-1541) daarmee kennis gemaak en dit ook so aanvaar (Van 't Spijker 1970:365, 392, 420; Henderson 1962:32 e.v.). Bucer self het hierdie vier ampte nie konsekwent as vasstaande aanvaar nie en uit sy geskrifte is dit duidelik dat hy dit ook dikwels beklemtoon het dat daar slegs drie (selfs net twee) ampte is, naamlik dié van herderlike diens, die versorgers van die armes en die diens van diegene wat die jeug in die kerk moet onderrig. Laasgenoemde groep, ook genoem die doctores, reken Bucer by die herders of presbiters. Hulle taak was meer die verklaring van die Skrif, leiding by teologiese dispute, die voorkoming van dwaling, en die bestryding van kettery en skeurmakers. Hulle kon die 
bedienaars of herders in die prediking bystaan, omdat die doctores God se gawe aan sy kerk en 'n spesialisasie van die presbiter se diens is (Van 't Spijker 1970:393).

Dankbaar (1964-1965:139) meen dat die doctores by Bucer nie net leraars ten opsigte van die Teologie of bedienaars van die Woord was nie, maar dat hulle onderrig in die literariese vakke gegee het. Hy wou die totale onderwys eerder aan die kerk as aan die owerheid bind. Dit is juis hierdie standpunte van Bucer wat Calvyn beïnvloed het.

Die amp van doktor in die Teologie was by Bucer dus 'n deelfunksie of spesialisasie van die presbiteriaat en het veral op die doctrina gefokus. Die doctor en doctrina hoort saam. Hierin is daar ooreenstemming met die standpunte in die Middeleeue waar die doctores ook op die leer of dogma van die kerk moes fokus. In die geval van Bucer en ook Calvyn later, het hulle ' $n$ ander reformatoriese visie op die waarheid van die evangelie en die leer van die kerk gehad, wat dan veral deur die doctores bedien en verdedig moes word (Posthumus Meyjes 1973:40-41).

\section{Calvyn se standpunte}

Die kerkhistorikus WF Dankbaar vanuit Groningen het in 'n volledige en uitvoerige artikel oor die doktoreamp by Calvyn geskryf (Dankbaar 1964-1965:135-165) en chronologies die verskillende uitsprake en stellings van Calvyn behandel (vgl. ook Henderson 1962:32-71). Hierdie artikel volstaan dus met 'n oorsigtelike weergawe van Calvyn se standpunte in so verre dit vir die artikel se doeleindes relevant en belangrik is.

Dit is opmerklik dat Calvyn in sy stellings en verwysings na die diens van die doktor of professor in die Teologie, nie net by Bucer aansluiting gevind het nie, maar ook by die eeue oue kerklike tradisie daaroor. Dit was ook vir Calvyn belangrik dat daar in die kerke en met die oog op die opbou en toerusting van die kerk in die algemeen sodanige diens of amp moet wees.

Die eerste keer wat Calvyn (1961:268-270) oor die funksie van die doktor geskryf het, was in 1539, in sy kommentaar op Romeine 12:7. Hier is daar sprake van die begrip didaskalos of in Latyn, doceo en doctrina. Hy beklemtoon die feit dat die kerk deur die doctrina of leer opgebou word en dat die funksie van doctores hiervoor verantwoordelik is. Hy onderskei hier ook tussen die funksie van die herder en dié van die leraar of doctor. Eersgenoemde is verbonde aan die plaaslike kerke waar hy veral die lidmate tot geloof moes opwek. Alhoewel hy ook lerend besig was, was dit egter veral die taak van die doctores om op die grondslag van die doctrina alle gelowiges of die hele kerk in die geloof op te bou en toe te rus (Dankbaar 1964-1965:151-152).

In sy Ordannances ecclesiastiques van 1541 (vgl veral artikel 2; Pont 1981:23) vind 'n mens nou vir die eerste keer dat Calvyn spesifiek van vier dienste in die kerk melding maak, waarvan die doktore een is. Hulle taak is veral op die onderrig van die gelowiges in die heilige leer gerig, sodat die suiwerheid van die evangelie nie deur onkunde of verkeerde opvattings geskaad word nie. Verder meen Calvyn dat die onderrig in die leer veral aan die jeug moet geskied en dat daar 'n skool opgerig moet word waar opleiding kan geskied vir sowel die bedienaars van die Woord as vir diegene wat in die burgerlike lewe moet dien (vgl. artikels 43-45; Pont, 1981:29).

Dit is eienaardig dat Calvyn twee jaar later, in sy Institusie (Calvyn [1543] 1991:4,4,3) slegs weer drie ampte of dienste in die kerk noem. Hy integreer hierin egter die diens van doktor in die Teologie met die diens van die herder. Die herder is vir die diens van die Woord, die sakramente en die tug verantwoordelik, terwyl die doktor vir die uitleg van die Skrif verantwoordelik is, sodat die voortgang van die suiwere leer gewaarborg kan word (Dankbaar 1973-1965:152). Bohatec (1961:452-453) wys daarop dat die kerk albei funksies, 'Pastoren und Lehrer' [herder en leraar] nie kan ontbeer nie.

In Calvyn ([1546] 1960:270-273) se kommentaar op 1 Korintiërs 12:28 (oor die funksies van die profete en die leraars), saamgelees met Handelinge 13:1 (wat oor die profete en die leraars in Antiogië handel) meen hy dat die leraars se werk baie nóú by die van die profete van ouds aansluit en dat hulle hulle veral moet toespits op die bewaring en die verbreiding van die suiwer en gesonde leer in die kerk. Dit onderskei hulle van die herders.

Vir die eiesoortigheid van die doktor in die Teologie, beroep Calvyn hom veral op Efesiërs 4:7-11. Hy maak van herders en leraars twee verskillende funksies (Dankbaar 1964-1965:142-145). Hy is bewus van ander standpunte en van verskillende interpretasies van Efesiërs 4:11, naamlik dat die Griekse grammatika sodanig verstaan behoort te word dat die uitdrukking herders en leraars op een amp of diens dui. Tog meen hy dat dit wel onderskei kan word, maar op so 'n wyse dat die leraar of doktor sy diens ook herderlik moet doen en ook toegelaat mag word om te preek; die herder behoort op sy beurt sy diens ook lerend en ter wille van die suiwer leer te verrig. Alle leraars moet nie noodwendig herders wees nie en alle herders nie ook noodwendig leraars nie. Laasgenoemde baseer hy op die verskil in bekwaamhede of gawes (facultates; Calvyn 1965:179-180; Dankbaar 1964-1965:147).

Met die laaste uitgawe van sy Institusie (Calvyn [1543] 1991:4,3,1-9; 4,1,1) onderskei Calvyn duidelik vier dienste met verwysing na Efesiërs 4:11. Die aksent by die diens van die leraars is dan weereens op die vertolking van die Skrif gerig met die oog op die bewaring en uitbouing van die gesonde leer onder die gelowiges (Calvyn [1543] 1991:1320).

Nog duideliker blyk dit in die Ordannances ecclesiastiques van 1561 (Pont 1981:23) waar die vier dienste, soos reeds vanaf 1541, behou word. Sedert 1541 is die skool wat toe in vooruitsig gestel is, opgerig. 
Samevattend kan gestel word dat Calvyn tussen die doktoreamp in die enger en die ruimer sin onderskei. Die doktoreamp in die enger sin verwys na die teologiese doktor of professor wat 'n kerklike amp of diens aangedui het, omdat hy ook 'n herder was. Die doktore-amp in die ruimer sin verwys na die doctores wat in die algemene onderwys betrokke was. Al het hy dit ook as 'n kerklike werk beskou, was dit losser van die kerk en nouer aan die owerheid verbind. Dit was veral ten opsigte van die doktore-amp in die enger sin waarvoor Calvyn 'n Skrifbegronding gesoek het (Dankbaar 1964-1965:159-160).

Dit moet ook in gedagte gehou word dat Calvyn altyd die eenheid tussen die dienste of ampte beklemtoon het. Al die dienste is organe van die Heilige Gees en moet as 'n eenheid saam aan God en sy kerk diensbaar wees: 'sicut varii toni in musica suavem melodiam conficiunt' ['net soos die verskillende tone in die musiek saam 'n skoon melodie maak'] (art. 51, 196; Plasger 2009:330).

\section{Die tyd van die Reformasie van die sestiende en sewentiende eeue met besondere aandag aan die kerklike besluite en ontwikkelings}

Haitjema (1925:183-212) dui in sy artikel oor Calvyn en die oorsprong van die Nederlandse gereformeerde kerkreg duidelik aan dat daar duidelike en opvallende ooreenkomste tussen Calvyn se Ordannances ecclesiastiques van 1561 en die artikels van Wesel van 1568 is - veral ook ten opsigte van die vierde diens (Haitjema 1925:201-202).

Die Weselse vergadering van 1568 het bestaan uit ' $n$ aantal kerklike persone en nie uit wettige afgevaardigdes van kerke nie. Dit het 'n sterk Nederlandse karakter gedra.

Volgens Haitjema (1925:208-211) is die sterk nasionale karakter by Emden in 1571 verdring of getemper deurdat die Walendom daar sterk gefigureer het. Dit is blykbaar die rede waarom die artikels van Emden ook ten opsigte van die aantal ampte van die Weselse bepaling verskil het. In die Disciplines ecclesiastique van die Franse kerke van 1559 is daar slegs sprake van die drie dienste, naamlik bedienaars van die Woord, die ouderlinge en die diakens (Pont 1981:49-50). Die Franse benadering het uiteraard 'n effek gehad op die oortuiging van die Nederlands-Calvinistiese standpunt wat in Wesel na vore gekom het.

Van die ideaal wat Wesel gehad het dat die doctores 'n volledig kerklike diens moes wees en ook vir die opleiding van die bedienaars verantwoordelik moet wees, het niks tereg gekom nie. By Emden in 1571 en by die provinsiale sinode van Dordrecht in 1574 is daar geen verwysing na 'n vierde diens oftewel die doktore-amp nie.

Bouwman (1928:497) wys daarop dat die gedagte aan 'n formele plek of universiteit waar predikante opgelei kan word gelukkig in 1575 gerealiseer het met die oprigting van die eerste universiteit in Nederland, naamlik in Leiden. Hieroor het die kerke egter geen seggenskap gehad nie, omdat dit deur die owerheid opgerig en beheer is. Die sinode van Dordrecht van 1578 het bepaal dat die professore by Leiden die belydenisskrifte moet onderteken.

Die oprigting van 'n universiteit waar Teologie los van die kerk aangebied is en predikante opgelei kon word, het die kerke ietwat verleë gelaat, omdat die kerklike diens (doktore-amp) nie meer in die kerklike ordes bepaal is nie en omdat die beheer en toesig daaroor uit hulle hande was. Dit was waarskynlik die rede waarom die sinodes te Middelburg (1581) en te 's-Gravenhage (1586) weer die doktore-amp in die kerkordes wat daar goedgekeur is, bygevoeg het (vgl Dankbaar 1964-1965:163; Bouwman 1928:496-498; Bavinck 1899:1-78).

Die sinode van Middelburg (1581) het ten opsigte van die amp van die doktore (toe ook genoem professore; Pont 1981:147) in artikel 2 van die kerkorde bepaal dat die amp van die doktore behels om die Heilige Skrif uit te lê, en 'voor de zuiwere leer te waken'. Hulle moes ook die belydenis onderteken. Die nasionale sinode van 1586 te 's-Gravenhage het hieraan niks verander nie.

In 1618 en 1619 by die nasionale sinode van Dordrecht is dit opnuut in artikel 2 vasgestel dat daar vier dienste sal wees. Artikel 18 is soos volg geformuleer: 'Het ambt der doctoren of professoren in de theologie is, de Heilige Schrifture uit te leggen, en de zuivere leer tegen de ketterijen en dolingen voor te staan' (Pont 1981:178).

In die jare daarna het die owerhede geen inmenging van kerklike kant in die universiteite geduld nie en die meeste teologiese professore was nie bereid om die Formuliere van Eenheid te onderteken nie, aangesien hulle daarmee aan die gesag van kerklike vergaderings onderwerp sou wees. Hulle het nie die begeerte gehad om in die kerklike doktore-amp te staan nie (Dankbaar 1964-1965:164; Haitjema 1951:24).

Hierdie toedrag van sake het noodwendig bygedra tot die spanning tussen die kerk en die universiteit. Daarom het die kerke byvoorbeeld hulle eie kerklike eksamens bepaal vir die toelatingseksamens van die bedienaars van die Woord (Dankbaar 1964-1965:164).

\section{'n Kritiese evaluering van die begronding van die vierde diens in die Skrif}

Calvyn se beroep op die Skrif, naamlik op tekste soos Efesiërs 4:11, Romeine 12:7, 1 Korintiërs 12:28 en Handelinge en sy algemene verwysings na die belangrike aksent van die waarheid van die evangelie, asook die prominente aktiwiteit van lering wat 'n mens in die Nuwe Testament teëkom, getuig van sy respek vir die gesag van die Skrif en dat hy sy ampsbeskouing in die Skrif wou 
fundeer. Dankbaar (1964-1965:160-161) is daarvan oortuig dat Calvyn nie daarin geslaag het om die doktore-amp in die voorskrifte van die Skrif te begrond nie, omdat sy beskouing was dat dit soos die ampte van die bedienaars van die Woord, die ouderlinge en die diakens deur die apostels onder inspirasie van die Heilige Gees ingestel moet wees.

Jansen (1952:12-14; 81-83) is uitgesproke daaroor dat Calvyn se beroep op Efesiërs 4:11 (en ook sy verwysings na Hand 13:1; Rom 12:7; 8; 1 Kor 1:5; 12:28) nie oortuig nie. Hy meen dat die Skrif slegs die drie ampte leer wat die gereformeerde kerke in die Nederlandse Geloofsbelydenis se artikel 30 bely. Jansen glo dat artikels 2 en 18 van die Dordtse Kerkorde, wat deur heelwat kerke so aanvaar word, verander moet word sodat die verwysing na die doktore-amp daarin geskrap word.

Oor die vraag of 'herders en leraars' in Efesiërs 4:11 op een of twee dienste dui, het Versteeg (1988) oortuigend eksegeties aangetoon dat dit op een diens of amp dui en hy stel dit soos volg:

Gezien de constructie in het Grieks zullen we bij de herders en leraars hebben te denken aan mensen die een en hetzelfde ambt bekleden. In het Grieks zijn de zelfstandige naamwoorden 'herders' en 'leraars' aan elkaar verbonden door het verbindingspartikel ...

En

... terwijl het eerste zelfstandige naamwoord voorafgegaan wordt door een bepaald lidwoord en het tweede niet. In zo 'n geval geldt het bepaalde lidwoord voor beide zelfstandige naamwoorden en gaat het bij de beide zelfstandige naamwoorden om èèn persoon of zaak. (bl. 60-62)

Ook Grosheide (1960:66) meen dat dit op een diens dui: 'Het gaat om herders, die ook leraar zijn.'

Versteeg (1988:61) merk op dat herderwees en leraarwees dus twee aspekte van een amp is. Hy wys verder daarop dat die leraars inderdaad baie prominent in die Nuwe Testament genoem word; vergelyk Paulus se verwysing daarna in 2 Timoteus 2:2 waar Timoteus aangemoedig word om dit wat hy gehoor het, toe te vertrou aan mense wat bekwaam sal wees om dit ook weer aan ander te leer.

In hulle verklaring van artikels 2 en 18 van die kerkorde meen Meulink en De Wolff (1967:24-25, 57-60) dat hoewel die doktore-amp nie in die Skrif voorgeskryf word nie, so 'n amp tog wel skriftuurlik is. Vergelyk hier byvoorbeeld Handelinge 18:24, 1 Timoteus 4:16 en 1 Johannes 4:1 en verder ook dat dit 'bij het opkomen van allerlei dwalingen en door de voortgang der wetenschap uit de behoefte van de practijk geboren' is (Meulink \& De Wolff 1967:25). Die doktor in die Teologie is volgens hulle dus 'n bedienaar van die Woord met ' $n$ besondere werksaamheid wanneer hy die Woord uitlê en dwalings en ketterye teenstaan, maar dan vanuit die kateder en aan 'n skool.

\section{Die verhouding tussen 'n kerklike en/of 'n universitêre teologiese opleiding}

Spoelstra (1989:122) wys daarop hoe daar in Nederland in die loop van die negentiende eeu, veral na die Afskeiding van 1834, hoofsaaklik twee uiteenlopende gedagtes bestaan het. Onder leiding van Kuyper was daar die oortuiging dat Teologie aan ' $n$ universiteit onderrig moet word. Dit het tot die oprigting van die Vrije Universiteit in Amsterdam gelei. Die ander tradisie - te Kampen - het op die spoor van die Afskeiding voortgegaan om predikante-opleiding as 'n suiwer kerklike taak te beskou en het dus die bestaan van die diens van professor as 'n kerklike diens gehandhaaf.

Dit is alreeds aangedui dat die universiteitsopleiding sedert die Middeleeue deur die Roomse en reformatoriese leiers en kerke as besonder belangrik geag is. Goeie akademiese kwalifikasies in die Teologie is as ' $n$ belangrike teenmiddel teen dwalings en ketters beskou, asook teen sektariese en charismatiese standpunte. Die Teologie as 'n wetenskap is besonder hoog aangeslaan en gerespekteer.

Sedert die ontstaan van die Universiteit van Leiden in Nederland in 1575 en ook ander wat later gevolg het, het daar ' $n$ spanning bestaan tussen die Teologie wat aan universiteite doseer is, en die Teologie wat die kerke nodig geag het vir die kerklike opleiding tot die diens van die Woord (Bouwman 1928:497 e.v.). Daar het 'n interessante en moeilike situasie hierdeur ontstaan. Binne die calvinistiese en kerklike tradisie is sedert die sestiende en vroeg-sewentiende eeue met die vasstelling van die Dordtse kerkorde, aanvaar dat ter wille van die suiwere Skrifuitleg en die verdediging van die waarheid teen dwalings, daar ' $n$ besondere diens, afsonderlik van die gewone diens van die bedienaar van die Woord, nodig is. Die universiteite het as inrigtings egter ook gemeen dat 'n universiteit onvolledig is sonder 'n Fakulteit Teologie (vgl Meuleman 1991:1-27). Sedert die Middeleeue tot vandag toe het veral ook binne die reformatoriese tradisie 'n spanningsveld ontstaan tussen onafhanklike universiteite met teologiese fakulteite aan die een kant en kerklike teologiese skole aan die ander kant. Albei groepe wil en moet belydenisgebonde teologiese opleiding bied met die oog op die bediening van die Woord aan die kerk van Christus (Le Roux 2013:1-5).

Dit is opmerklik dat binne die calvinistiese tradisie daar 'n deeglike besef bestaan dat Teologie van hoë gehalte moet wees, juis ter wille van die bevordering en verdediging van die waarheid van die evangelie. Die kerke binne die reformatoriese tradisie het egter nie teenoor die universiteite daarin geslaag om 'n konfessionele dissipline teenoor die fakulteite se teoloë te verkry nie. Dit maak die vraag dus belangrik hoe albei aspekte, naamlik Teologie van hoë gehalte en tegelyk kerklike dissipline wat teen dwaalleer behoort te reageer, verkry en verseker kan word.

Die tergende vraag is hoekom dit so belangrik is dat teologiese opleiding aan ' $n$ universiteit aangebied moet word. Sonder 
om in diepte of volledig op die wese en taak van 'n unversiteit as instelling in te gaan, word met enkele opmerkings daaroor volstaan wat vir hierdie artikel relevant is.

Meuleman (1991:1-9) verwys byvoorbeeld na Newman wat die universiteit as instelling as 'n noodsaaklike en onontbeerlike produk van die beskawing waardeer - 'n instelling wat studente behoort te begelei tot iets wat hy 'n filosofiese habitus noem. Die begeleiers is mense wat so verryk en toegerus is dat hulle wetenskaplik en nuut met die lewe en die wêreld kan omgaan. By universiteite gaan dit daarom nie eerstens om die sogenaamde rekende denke nie, maar om nadenke. Die fokus is dus nie op beplanning, ordening, sistematisering en administrasie nie, maar op diep kritiese en skeppende denke wat deur navorsing verkry moet word (Le Roux 2013:1-2). Uit die Duitse universiteitsmodel wat onder leiding van Von Humboldt in die begin van die negentiende eeu ontwikkel is, het veral geblyk dat universiteite op die waarheid self moet fokus, deur die waarheid te soek en nie om as 'n soort vakskool te funksioneer waar kennis toegepas word nie (Meuleman 1991:3-5).

Die aksent dat universiteite jaloers op deeglike en wetenskaplike navorsing behoort te wees ter wille van die groei en ontwikkeling van die wetenskap op alle terreine, geld ook ten opsigte van Teologie. Daar is dus geargumenteer dat indien Teologie as 'n wetenskap beskou word, dit ook aan wetenskaplike standaarde behoort te voldoen (Rossouw 1993:124-138)

Le Roux (1992:291-300; 2013:1-5) skryf oor die noodsaaklikheid van wetenskaplike Teologie en spreek hom tereg uit teen die dualisme van geloof en rede en van universiteit teenoor seminarium. Teologiese opleiding wat net daarin belangstel om studente prakties met metodes en tegnieke toe te rus asook met die toepassingsaspekte van teologiese vakke met die oog op die praktyk van die kerklike bediening, kan nie op universiteitskwalifikasies aanspraak maak nie. Die rede hiervoor is dat die epistemologiese, vakfilosofiese en navorsingselemente wat meehelp dat studente tot kritiese, selfstandige en wetenskaplike denke gelei word, in sodanige gevalle afwesig is. Hoewel daar 'n spanning tussen geloof en rede bestaan, behoort dit nie noodwendig as negatief ervaar te word nie, meen Le Roux (2013:3).

Uit die historiese agtergrond sowel as uit die reformatoriese aksente oor Teologie en teologiese opleiding is dit duidelik dat die Teologie ' $n$ kardinale en belangrike funksie het om te vervul ten opsigte van die waarheid van die evangelie, asook die uitleg en die verdediging daarvan. In die tyd van die Reformasie het geleerde mense soos Luther en Calvyn juis die leer van die kerk en die praktyke wat aan die orde was, ontmasker en hervorm. Aan die ander kant was daar ook dikwels teoloë wat buite die waarheid van die evangelie om gefunksioneer het en wat deur die kerke as dwaalleraars verklaar is.
Die ideaal blyk te wees dat Teologie wat tegelyk as 'n kerklike en universiteitsaangeleentheid beskou kan word, aan die waarheid en die suiwer verstaan van die evangelie sowel as aan teologies-wetenskaplike vereistes moet kan beantwoord. Hierdie spanning mag nie ter wille van goeie Teologie ontaard in 'n skeiding van geloof en rede nie, maar dit moet as 'n gesonde spanning beskou word wat tot semper reformanda moet bydra.

\section{Die professor in die Teologie soos dit veral binne die konteks, standpunte en omstandighede van die GKSA na vore kom}

In die laaste deel van die artikel word gefokus op die situasie binne die Gereformeerde Kerke in Suid-Afrika (GKSA), met 'n toespitsing op die volgende aspekte:

- Die aanvaarding van die diens van professor as ' $n$ vierde diens, ooreenkomstig die Dordtse kerkorde;

- die ooreenkoms met die Noordwes-Universiteit (voorheen die $\mathrm{PU}$ vir $\mathrm{CHO}$ ) ten opsigte van teologiese opleiding - sedert die formalisering daarvan in 1945; en

- die gewysigde formulering van artikel 18 van die kerkorde in 1964.

\section{Die GKSA en die doktore-amp of die diens van professor in die Teologie}

Met die stigting van die GKSA in 1859 is die kerkorde van Dordrecht 1618 en 1619 aanvaar en tydens die eerste sinode van die GKSA in 1862 te Reddersburg formeel goedgekeur. Sedertdien is dit steeds die standpunt van die GKSA dat daar vier dienste is (vgl. artikel 2), en dat artikel 18 wat die diensplig of amp van 'n teologiese professor beskryf, op artikel 18 van die oorspronklike bepaling van 1618 en 1619 berus.

In 1869 is ' $n$ Teologiese Skool vir die opleiding van predikante en ook vir ander studente wat hulle byvoorbeeld vir die onderwys of ander beroepe wou bekwaam te Burgersdorp in die Kaapkolonie van destyds, opgerig. Sedert daardie tyd het die kerke verantwoordelikheid vir die opleiding van die bedienaars van die Woord aanvaar en dit uitgevoer. Dit was tegelyk ook die begin van die universiteit wat later bekend geword het as die Potchefstroomse Universiteit vir Christelike Hoër Onderwys.

Laasgenoemde inrigting het volgens die besluit van die owerheid met die Universiteit van Noordwes (te Mafikeng) saamgesmelt en is sedert 2004 bekend as die NoordwesUniversiteit (NWU). Dit het drie kampusse, naamlik te Mafikeng, Vanderbijlpark en Potchefstroom. 'n Fakulteit Teologie van die NWU bestaan op die Potchefstroom kampus. Tussen die NWU en die Teologiese Skool van die GKSA bestaan daar 'n besondere historiese en geestelike band. 


\section{Die ooreenkoms met die Noordwes-Universiteit (voorheen die PU vir $\mathrm{CHO}$ ) ten opsigte van teologiese opleiding sedert die formalisering daarvan in 1945}

Sinodes van die GKSA het veral sedert 1936 tot 1945 aandag gegee aan die vraag na 'n duideliker en meer formele basis van samewerking met die Universiteit (toe die Potchefstroomse Universiteits Kollege, of te wel PUK). In 1945 met die aanvaarding van 'n meerderheidsrapport (GKSA 1945:162-173, art. 163) is besluit op 'n behoorlik geskrewe ooreenkoms tussen die Teologiese Skool en die PUK. Die vernaamste redes of motiverings hiervoor was die volgende:

- Die handhawing van die besondere historiese band en etos tussen die Teologiese Skool en die Universiteit.

- Die noodsaaklikheid van goeie wetenskaplike Teologie wat die status van universiteitsteologie sal kan geniet, en wat predikante in staat sal kan stel om verdere grade in die Teologie te kan verwerf.

- 'n Universiteit sonder 'n Fakulteit Teologie sou onvolledig wees.

- Die bestaan van 'n afsonderlike Teologiese Fakulteit van die Universiteit naas die kerklike teologiese skool sal tot 'n daadwerklike skeiding lei, wat moontlik tot konflikte en die verwaarlosing van 'n pragtige geleentheid kan lei, want 'deur 'n ooreenkoms word 'n juiste verhouding geskep tussen universitêre en seminaristiese opleiding' (GKSA 1945:166, 167).

- 'Aan die een kant moet ons die beginsel van die vaders handhaaf: opleiding vir die kerk deur die kerk. Aan die ander kant egter: geen universiteit sonder Teologie nie' (GKSA 1945:166).

- 'Die PUK kan 'n sterk teologiese fakulteit opbou wat bevorderlik sal wees vir die uitbouing van die Geref. Teologie in Suid-Afrika' (GKSA 1945:169).

- Die selfstandigheid van albei inrigtings word gehandhaaf en word nie waterdig geskei of saamgesmelt nie.

Die ooreenkoms van 1945 is met die verloop van jare in terme van die relevante bepaling daarin soms gewysig en aangepas sonder om die essensie te verander. Die jongste geformuleerde ooreenkoms dateer sedert 2006 toe sowel verteenwoordigers van die GKSA as van die NWU dit namens hulle mandaatgewers onderteken het (vgl GKSA 2006:806).

Hierdeur is gepoog om die balans te handhaaf tussen die kerklike opleiding (waartoe artikels 2 en 18 van die kerkorde die kerke verplig) en die universitêre opleiding (wat tipies wetenskaplik met die Teologie as wetenskap omgaan). Dit bly steeds ' $n$ unieke ooreenkoms wat ontstaan het en dit word steeds so gehandhaaf.

\section{Artikel 18 van die kerkorde van die GKSA soos gewysig deur die Nasionale Sinode van 1964}

Vanaf 1955 is daar op die agenda van die Nasionale Sinodes van die GKSA aandag gegee aan 'n moontlike verandering van die kerkorde. In 1961 is ' $n$ rapport ingedien waarvolgens die teks van die kerkorde ingrypend verander sou word, maar in 1964 (GKSA 1964:52-74) was dit duidelik dat die kerkorde slegs in 'n geringe mate verander is ooreenkomstig artikel 86 van die kerkorde - dit is veral aangepas by die tyd en omstandighede van die GKSA (vgl Spoelstra 1989:22).

Een van die artikels wat wel in 1964 verander is, is artikel 18. Dit is interessant om op te merk (GKSA 1961:322) dat 'n gewysigde kerkorde in 1961 voorgestel is waarin daar van drie dienste sprake was by artikel 2, terwyl die vierde diens van professore weggelaat is.

In 1964 is die vier dienste (art. 2 en 18) behou, maar die formulering van die artikel is wel verander. Vóór 1964 het dit soos volg gelui: 'Die amp van die doktore of professore in die Teologie is om die Heilige Skrif uit te lê, en die suiwere leer teen die ketterye en dwalinge te verdedig' (GKSA 1964:56).

\section{Dit is egter soos volg verander:}

Die dienspligte van die professore aan die Teologiese Skool is om bedienaars van die Woord op te lei, die Heilige Skrif uit te lê en die suiwere leer teen die ketterye en dwalinge te verdedig. (GKSA 1998:18)

Op die oog af mag dit na 'n goeie verandering lyk omdat die klem nou duidelik op die opleiding van die bedienaars van die Woord val. Oppervlakkig beskou lyk dit asof die dienspligte (let op die meervoud) van professore duidelik in drie aspekte of pligte uiteenval, soos Visser (1999:92-93) dit inderdaad ook verstaan, naamlik die opleiding van bedienaars van die Woord, die uitlegging van die Woord, en die verdediging van die suiwer leer.

Die Nasionale sinode (GKSA 1964) het die verandering soos volg gemotiveer of verdedig, maar daarmee nie elke aspek van die verandering verduidelik nie:

Die kwalifikasie Teologiese Skool is nodig omdat Professore in die Teologie nie noodwendig aan die kerklike skool verbonde is nie. In die verband moet daarop gewys word dat die benaming 'dienste' in artikel 2 'n ruimer betekenis het as wat gewoonlik verstaan word onder 'ampte'. Dit kom duidelik na vore as gelet word op die Latynse uitgawe van die K.O. Ons wys op die volgende:

1. In art. 2 word 'functio' gebruik wat dui op 'n ruimer betekenis van diens.

2. In arts. 16, 23, en 25 waar gehandel word oor die drie besondere ampte word 'officium' gebruik. Bouwman verklaar dit as: 'de vervulling van een ambt of een plicht' (1928, Deel I, p. 366).

3. In art. 18 waar gespreek word van die Professore in die Teologie word 'munus' gebruik.

Dit is dus duidelik dat art. 2 'n benaming gebruik wat die drie besondere ampte sowel as die Professore in die Teologie insluit terwyl dit dan later in die K.O. onderskei word deur twee verskillende benaminge (bl. 67-69).

Ernstige kritiek kan egter op hierdie skynbaar goedbedoelde wysiging van artikel 18 gelewer word: 
- Die eerste punt van kritiek is dat die verandering van die enkelvoud amp/diens in artikel 18 (munus) sonder verduideliking na die meervoud dienspligte verander is; munus beteken die taak en/of funksie waarmee iemand belas is of wat sodanige persoon as 'n verantwoordelikheid het (Georges 1882:1281).

- Die tweede verandering, naamlik die wysiging van 'professore in die Teologie' na 'professore aan die teologiese skool' in artikel 18 is gedoen sonder om die bewoording van artikel 19 ook te verander. In artikel 19 word van 'studente in die Teologie' (soos 'professore in die Teologie' by die oorspronklike artikel 18) gepraat. Die wysiging word wel in die rapport van die betrokke deputate aan die sinode verklaar, sonder om die presiese konsekwensie daarvan te deurgrond. Hier word 'n subtiele, maar duidelike oorgang gemaak: die woorde, professore in die Teologie, waar die aksent op die teologiese diens of amp geplaas word, word vervang met professore aan die teologiese skool. Daarmee verskuif die aksent van die saak van Teologie na 'n instituut of skool as instelling waaraan die professore verbind is. Die bedoeling van die oorspronklike artikel, naamlik om 'n beskrywing van die diens van die professore in die Teologie te gee, word dus verander. Hierdie verandering lei waarskynlik daartoe dat die klem by artikel 18 verskuif het van die diens van die teologiese professore na die aktwiteite by die Teologiese Skool as instelling met sy eie beheerstruktuur onder leiding van kuratore. Die taak en funksie van die kuratore as toesighouers en versorgers van die teologiese professore is uiteraard noodsaaklik en belangrik, maar impliseer nie dat die diens in die Teologie die verantwoordelikheid van ' $n$ skool of van ' $n$ kuratorium is nie. Die professore in die Teologie is primêr vir die diens van Teologie in belang van die kerke verantwoordelik en aanspreeklik. Die veranderde artikel kan veroorsaak dat die aksent op die diens van teologiese professore vervang word met 'n aksent op die instelling en sy aktiwiteite. Die taak en verantwoordelikheid van kuratore word in die besluite van die sinodes gereël, en nie in artikel 18 nie. Oorweging sou gegee kan word aan die moontlikheid daarvan om artikel 18 na sy oorspronklike bewoording terug te verander en om dan ' $n$ tweede deel by die artikel te voeg waarin die toesighouding oor die vierde diens na analogie van artikels 16 en 23 van die kerkorde gereël word.

- Die derde opvallende verandering is dat die indruk geskep word, strydig met die oorspronklike bedoeling en inhoud van artikel 18, dat die professore in die Teologie (of soos dit verander is: aan die teologiese skool) drieërlei pligte het. Vroeër is aangedui dat Calvyn en die kerke in die reformatoriese tyd die klem duidelik op twee hoofsake laat val het soos dit ook in die formulering van die sinodes van 1581 tot 1618 en 1619 en daarna in baie gereformeerde kerke onderhou word. Die klem is naamlik dat die professore verantwoordelik is vir die interpretatio verbi Divini, en tweedens vir die disputatio of verdediging van die suiwer leer teen die dwalings. Hulle diens was op die belang van al die kerke in die bepaalde kerkverband gefokus. Uiteraard is die opleiding van die bedienaars van die Woord by hierdie diens ingesluit, want wanneer die professore hulle tweeledige dienswerk of munus verrig, naamlik interpretatio en disputatio, sluit dit hulle werk aan die skool of plek(ke) in waar studente opgelei word met die oog op die diens van die Woord. Die opleiding tot die diens van die Woord was nie bedoel as iets afsonderliks naas die taak van die professore, naamlik om die Skrif uit te lê, te bevorder en te verdedig nie. Hierdeur het hulle in diens van die waarheid van die evangelie gestaan. Jansen (1952:83) wys daarop dat Calvyn en die reformatoriese kerk hiermee die grondslag vir ' $n$ teologiese ensiklopedie gelê het, aangesien dit in die Teologie om die uitleg en verdediging van die waarheid gaan. Dit sluit die hele teologie in en is later in bibliologiese, ekklesiologiese, dogmatologiese, diakoniologiese (of prakties-teologiese) en missiologiese vakke onderskei. In al hierdie vakke gaan dit om die uitleg van die Skrif en die verdediging daarvan teen dwalings.

- Met 'professore in Teologie' in die oorspronklike formulering van artikel 18, word juis daardie professore bedoel wat as bedienaars van die Woord volgens die relevante artikels van die kerkorde en sinodebesluite, ordelik beroep en toegelaat is tot hierdie vierde diens. Artikels 2 en 18 handel juis oor kerklike dienste en/of ampte, vanselfsprekend onderskeie van teoloë wat slegs deur die universiteit benoem is.

- Verder is die oorspronklike professore of doktore in die teologie 'n veel ruimer en beter aanduiding van die skopus en terrein waarin hierdie dienaars (professore) werksaam moet wees. Die verwysing of kwalifikasie, aan die Teologiese Skool, beperk die taak van hierdie diens tot werksaamhede of pligte aan die teologiese skool, asof die totale diens in die opleiding van die bedienaars van die Woord opgaan. Die bedoeling van die artikel, teen die agtergrond en ontwikkeling daarvan vanaf die sestiende eeu, sluit wel die belangrike diens van die opleiding van studente in die Teologie (art. 19) in, maar is nie daartoe beperk nie. Hierdie veranderde formulering gee waarskynlik aanleiding tot die verkeerde gedagte dat die kerklike professore predikante oplei terwyl die universiteitsprofessore teoloë verder moet oplei, byvoorbeeld vir akademiese grade - ook nagraadse grade. Dit skep die indruk dat die kerke en diegene wat in hierdie diens besig is, nie ook ' $n$ verantwoordelikheid het ten opsigte van die aanbieding van Teologie wat breër strek as die opleiding van studente met die oog op die toelating tot die diens van die Woord alleen nie. Dit sou suiwerder wees om te stel dat professore in die Teologie wat kerklik sowel as universitêr verbonde is, as deel van die uitoefening van hulle diens (munus), opleiding in die Teologie moet bied. Vanweë die aard van 'n universiteit lei tot dit die verkryging van teologiese grade. Indien daar egter geen universiteit sou wees waaraan die professor in die Teologie verbonde sou kon wees nie, is daar nog steeds ' $n$ behoefte by die kerke dat aan diegene wat later vir die diens van professor in die teologie benodig word, sodanige opleiding ook tot op die hoogste vlak (kerklik) gebied behoort te word. 
- Die wysiging wat die Sinode van 1964 aangebring het, blyk dus ongemotiveerd en verwarrend te wees en behoort ernstig heroorweeg te word.

\section{Enkele konklusies en perspektiewe}

- Uit die geskiedenis en historiese ontwikkeling voor, tydens en na die Reformasie van die sestiende eeu blyk dit duidelik dat die kerk deur die eeue 'n hoë premie op die leer en op die leraar(s) geplaas het. Die doctores in die Middeleeue en in die Reformasie het 'n prominente en gerespekteerde dienswerk as doctores theologiae gelewer.

- Die sogenaamde vierde diens, of te wel die doktore-amp wat in die Dordtse kerkorde van 1618 en 1619 behoue gebly het en in 'n groot aantal gereformeerde kerke in die wêreld steeds so aanvaar word, kan nie direk op bepaalde tekste in die Nuwe Testament begrond of gefundeer word nie. Calvyn was geneig om dit te doen met sy verwysing na Efesiërs 4:11. Calvyn het egter nie onverskillig met sy eksegese van Efesiërs 4:11 omgegaan nie. Hy laat blyk dat die diens van herder en leraar nie geskei kan word nie. Tog was die leer van die kerk en die funksie van lering vir Calvyn baie belangrik soos dit ook in die eeue vantevore die geval was. Hy het dit goed beklemtoon dat die twee aspekte of funksies van die diens van die Woord, naamlik die herderwees en leraarwees vir die opbou en toerusting van die kerk onontbeerlik is.

- Die argument dat die doktore-amp uit die praktiese nood van die kerk gebore is en daarom aanvaarbaar is en wel ook kerklike gesag het, is nie net gevaarlik nie, maar onoortuigend. Indien dit so sou wees, sou daar geargumenteer kan word dat die praktyk vandag of môre weer ander ampte of dienste in die kerk nodig mag maak, en daar sou ook verder binne bepaalde ampte gedifferensieer kon word.

- Die diens van doktor of professor in die Teologie is in die eintlike sin steeds diens van die Woord. Tog is die aksent op die lerende aspek wat in die Ou en Nuwe Testament na vore kom, belangrik genoeg om tot die gevolgtrekking te kom dat die dienswerk wat die teologiese professor as bedienaar van die Woord verrig, nie met die inhoud en praktyke wat in die Nuwe-Testamentiese kerk te vinde is, in stryd is nie. Die herhaalde klem op die gesonde en die suiwer leer, op die waarheid en op die verdediging van die waarheid teen valse leraars en ketters, dien as 'n bewys daarvan. Die feit dat die waarheid van die evangelie van geslag tot geslag oorgedra moet word (2 Tim 2:2), is ' $n$ verdere bewys daarvan. Dit is aanvaarbaar dat die kerke nie net op die preskriptiewe tekste van die Skrif ordelike bepalings mag aflei nie, maar ook op die deskriptiewe tekste om sodoende vas te stel watter ordelike bepalings die gees van die Skrif adem. Ook in die belydenis (Nederlandse Geloofsbelydenis, artikels 30-32) bely die kerk dat die kerk toegelaat is om ter wille van die goeie orde en opbou van die kerk bepalings te mag opstel. In die kerkreg word hierin onderskei tussen die ius positivum [geldende, geformuleerde reg soos direk uit die Skrif verkry en afgelei] en ius permissivum [toegelate reg].
- Die dienswerk van die teologiese professor as 'n toegeruste en gekwalifiseerde teoloog of leraar is as 'n funksie in die kerk onontbeerlik en noodsaaklik. Dit moet onderskei word van die bedienaars van die Woord wat as herders voltyds herderlike en ook lerende werk in 'n plaaslike kerk verrig; en ook van die sendeling wat kragtens artikel 7 van die kerkorde uitgestuur word om kerke te vergader, wat dit juis ook herderlik en lerend en onderrigtend doen. Hierdeur word die volk van God soos skape vergader en versorg. Die bedoeling en draagwydte van artikels 7 (tweede deel) en 18 van die kerkorde moet deeglik onderskei word.

- Dit sal moontlik 'n goeie reformatoriese optrede wees indien die sinodes van die GKSA weer aan die formulering van artikel 18 aandag gee. Dit behoort verander te word soos dit reeds in 1581 en in 1618 en 1619 in die tyd van die Reformasie kerklik geformuleer is en soos wat dit steeds by 'n groot aantal gereformeerde kerke gehandhaaf word.

- Die besondere band en ooreenkoms wat daar tussen die GKSA en die NWU ten opsigte van die teologiese opleiding van die bedienaars van die Woord ontstaan het en steeds bestaan, is ' $n$ kleinnood. Dit moet bewaar en gebruik word in belang van die deeglike kerklike teologiese toerusting sowel as vir die voordeel van die Universiteit. Spanning wat inherent deel hiervan is, moet deur die verantwoordelike partye en persone met verstandigheid en omsigtigheid reg en positief bestuur word, sonder dat die balans en wysheid wat uit die ooreenkoms blyk, versteur of vernietig word. Die gesonde spanning tussen die handhawing en uitbouing van die ware en suiwer leer en die beoefening van hoogstaande wetenskap in die Teologie, is innerlik deel van elke verantwoordelike en geroepe teoloog.

\section{Erkenning Mededingende belange}

Die outeur verklaar dat hy geen finansiële of persoonlike verbintenis het met enige party wat hom nadelig kon beïnvloed het in die skryf van hierdie artikel nie.

\section{Literatuurverwysings}

Bavinck, H. 1899, 'Het doctorenambt', in Bavinck, H., Verspreide geschriften, vol. 1:1-78, Zalsman, Kampen.

Bohatec, J., 1961, Calvins Lehre von Staat und Kirche mit besonderer Berucksichtigung des Organismusgedankens, Scientia, Aalen.

Bouwman, H., 1928, Gereformeerd kerkrecht, Kok, Kampen.

Calvyn, J., [1546]1960, 'The first epistles of Paul the apostle to the Corinthians', in D.W. Torrance \& T.F. Torrance (ed.), Calvin's commentaries, transl. by J.W. Fraser, pp. 270-273, Oliver \& Boyd, Edinburgh.

Calvyn, J., 1961, 'The epistles of Paul the apostle to the Romans and the Thessalonians', in D.W. Torrance \& T.F. Torrance (ed.) Calvin's commentaries, transl. by R. Mackenzie, pp. 268-270, Oliver \& Boyd, Edinburgh.

Calvyn, J., 1965, 'The epistles of Paul the apostle to the Galatians, Ephesians, Phillipians and Colossians', in D.W. Torrance \& T.F. Torrance (ed.), Calvin's commentaries, transl. by T.H.L. Parker, pp. 179-180, Oliver \& Boyd, Edinburgh.

Calvyn, J., [1543] 1991, Institusie van die Christelike godsdiens, vertaal H.W. Simpson, Calvyn Jubileumboekefonds, Potchefstroom.

Dankbaar, W.F., 1964-1965, 'Het doctorenambt bij Calvijn', Nederlands Theologisch Tijdschrif 19, 135-180.

Georges, K.E., 1882, Latijns woordenboek, Op nieuw bewerkt door prof. dr. Engelbregt, 4e druk, Wolters, Groningen. 
Gereformeerde Kerke in Suid-Afrika, 1945, Handelinge van die 29ste sinodale vergadering van die Gereformeerde gemeentes in Suid-Afrika, Die Weste, Potchefstroom.

Gereformeerde Kerke in Suid-Afrika, 1961, Handelinge van die 34ste sinodale vergadering van die Gereformeerde Kerke in Suid-Afrika, Herald, Potchefstroom.

Gereformeerde Kerke in Suid-Afrika, 1964, Handelinge van die 35ste sinodale vergadering van die Gereformeerde Kerke in Suid-Afrika, Herald, Potchefstroom.

Gereformeerde Kerke in Suid-Afrika, 1998, Kerkordeboekie van die Gereformeerde Kerke in Suid-Afrika, Administratiewe Buro, Potchefstroom.

Gereformeerde Kerke in Suid-Afrika, 2006, Handelinge van die 49ste nasionale sinode te Potchefstroom, V\&R, Pretoria.

GKSA kyk Gereformeerde Kerke in Suid-Afrika.

Grosheide, F.W., 1960, De brief van Paulus aan de Efesiërs, Kok, Kampen. (Commentaar op het Nieuwe Testament).

Haitjema, Th. L., 1925, 'Calvijn en de oorsprongen van het Nederl Geref Kerkrecht', in A. Goslinga (red.), Christendom en Historie, Holland, Amsterdam.

Haitjema, Th. L., 1951, Nederlands Hervormd Kerkrecht, Callenbach, Nijkerk.

Henderson, R.W., 1962, The teaching office in the reformed tradition: A history of the doctoral ministry, The Westminster Press, Philadelphia.

Jansen, Joh, 1952, Korte verklaring van de kerkenordening, Kok, Kampen.

Le Roux, J.H., 1992, 'Op die breuklyn (oor universiteit en teologiese fakulteit)', Nederduitse Gereformeerde Teologiese Tydskrif 33(3), 291-300.
Le Roux, J.H., 2013, Hoort teologiese opleiding aan 'n universiteit?, besigtig 29 Januarie 2013, by http://teo.co.za/articles/510/1/

Meuleman, G.E., 1991, 'Theologie aan de universiteit', Gereformeerd Theologische Tijdschrift 91(1), 1-27.

Meulink, H. \& De Wolff, I., 1967, Korte verklaring van de kerkenordening, Boersma, Enscede.

Plasger, G., 2009, 'Ecclesiology', in H.J. Selderhuis, The Calvin handbook, pp. 323-332, Eerdmans, Grand Rapids.

Pont, A.D., 1981, Die historiese agtergronde van ons kerklike reg, HAUM, Pretoria.

Posthumus Meyjes, G.H.M., 1973, 'Het doctorenambt in Middeleeuwen en Reformatie', Rondom het Woord 3, 21-45.

Rossouw, H.W., 1993, Universiteit, wetenskap en kultuur: Opstelle oor die krisis, uitdagings en geleenthede van die moderne universiteit, Tafelberg, Kaapstad.

Spoelstra, B., 1989, Gereformeerde kerkreg en kerkregering: 'n Handboek by die kerkorde, Hammanskraalse Teologiese Skool van die Gereformeerde Kerke in Suid-Afrika, Hammanskraal.

Steinlein, H., 1912, 'Luthers Doktorat', Neue Kirchliche Zeitschrift 23(S), 757-770.

Van 't Spijker, W., 1970, De ambten bij Martin Bucer, Kok, Kampen.

Versteeg, J.P., 1988, 'Het karakter van het ambt volgens Efeziërs 4:7-16', in P.J. Rossouw (red.), Gereformeerde ampsbediening, bl. 49-74, NG Kerkboekhandel, Pretoria.

Visser, J., 1999, Die kerkorde in praktyk, EFJS, Orkney. 